\begin{tabular}{|l|l|}
\hline \multicolumn{2}{|c|}{ Toppan Best-set Premedia Limited } \\
\hline Journal Code: AJES & Proofreader: Emily \\
\hline Article No: 843 & Delivery date: 23 July 2012 \\
\hline Page Extent: 27 & \\
\hline
\end{tabular}

\title{
Going My Way? Wending a Way Through the Stumbling Blocks between Georgism and Catholicism
}

\author{
By Mason GafFneY*
}

\begin{abstract}
This essay surveys the issues between Georgists and Roman Catholics in three classes: issues that are not peculiarly Roman Catholic (RC) but play out across faiths and denominations, issues that are peculiarly RC, and points of similarity and agreement. Addressed in this fashion are the tensions that arise between the social gospel and individual salvation, between specifics and glittering generalities, between noblesse oblige and governmental reform, between the doctrine of original sin and tabula rasa, between the rich and the poor, between the dignity of labor and the honor of predation, between democracy and authority, between the regulatory emphasis rooted in the philosophy of Aquinas and free markets, and between plain talk and gobbledegook.
\end{abstract}

\section{Introduction}

There have been and are many Georgist Catholics and Catholic Georgists. The divisions inside each group are perhaps as deep as the divisions between them. This bodes well for future cooperation between at least some Georgists and some Catholics.

Some outstanding Catholic Georgists or fellow-travelers in politics have been Fr. Edward McGlynn (see Gaffney 2000), Governor Al Smith, Mayor and Governor Edward Dunne, Mayor Daniel Hoan, Union leader Margaret Haley, Presidential Advisor Joseph Tumulty, Mrs. Henry George, Governor John Peter Altgeld, and Mayor Mark Fagan. Some current Georgist/Catholics are John Kelly of Peoria, Terry Dwyer of Canberra, Bryan Kavanagh of Melbourne, and David Kromkowski of Maryland. Some of them, like McGlynn and Smith, met stiff resistance from upper echelons of the Roman Catholic Church

*Mason Gaffney is Professor of Economics at University of California, Riverside.

American Journal of Economics and Sociology, Vol. ••, No. ••(・•, 2012).

(C) 2012 American Journal of Economics and Sociology, Inc. 
(RCC) hierarchy, but that is one of the internal divisions we will explore. Some, like Patrick Ford and Terence Powderly, succumbed to the pressure.

The hierarchy has also repressed Catholic land reformers of other stripes: the Worker Priests of France and the Liberation Theologists of Brazil, for example. The knee-jerk reaction has been to cry "Marxism" and clamp down. In turn, some Catholic land reformers in power have suppressed the RCC and confiscated its lands, as in Mexico. Catholic King Louis XV of France expelled the Jesuits, who did not return until 1814, under aegis of The Holy Alliance. Either way there has been considerable hostility. The hierarchy has generally allied with big landowners, while many priests, like France's Abbé Pierre, have identified with the landless.

This essay surveys the issues between Georgists and Roman Catholics in three classes: issues that are not peculiarly Roman Catholic (RC), issues that are peculiarly RC, and points of similarity and agreement. I have not come to reopen the Thirty Years' War. My hope and intent is to help the points of agreement override the differences.

\section{Generic Issues between Georgists and Clerics, and among Clerics of All Faiths and Denominations}

\section{The Social Gospel vs. Individual Salvation}

With the ascendancy of altar-calling evangelist Billy Graham, Protestant Christianity leaped far away from the Social Gospel of, say, Walter Rauschenbusch and Washington Gladden of the Progressive Era and the mild liberalism of The Christian Century. The Elmer Gantry phenomenon was of course well known before that, as was the "Monkey Trial" subculture of Dayton, Tennessee, but they were on the downswing. In the Cold War era, however, Protestant Americans suddenly responded en masse and without much discretion, flocking to caricatures of Graham, and televangelists like Bebe Patten, Jim and Tammy Bakker, Paul Crouch, Jimmy Swaggart, Pat Robertson, Gene Scott, Jerry Falwell and many others of like bent. They attacked the social gospel with as much vigor as they preached individual salvation. 
Recently, in heavily churched protestant Alabama, Professor Susan Pace Hamill, a committed southern Methodist allied with a Baptist school, sought to mobilize the churches to raise the puny property taxes levied on giant holders of timberlands, while raising the personal exemptions for the poor. She allied with popular Governor Bob Riley. They enlisted a substantial minority of the churches, but a majority, with most of the money, turned against them. The richer church leaders argued that a progressive tax system would undercut their role as charity-givers.

Nothing in Georgism makes one oppose individual salvation or embrace sin. George himself was floridly religious, and many clergy of all faiths took his part, while many anti-Georgist academicians sneered at his religious "emotionalism," as they called it. Marxists, too, and those who followed their fashions, belittled George's overt expressions of religious faith and feelings. Most Georgists, however, give priority to some kind of social gospel over individual salvation, which they see as rather narcissistic.

Some leading anti-Georgists, too, were leaders of the social-gospel movement. Protestant Professors John B. Clark and Richard T. Ely were highly visible, but their social gospel stayed well inside the comfort zone of rentier mainstays of the collection plate. They preached for privatizing all lands and protecting them from property taxation, while they traduced Henry George and his ideas and allies.

One RCC position on this, expressed by Brian Benestad (2012), is that overcoming evil deserves priority over improving human institutions. It is more than just "priority," but virtual exclusion of any social gospel. Benestad holds that worldly reforms may do more harm than good by misleading people into thinking the world may be saved without overcoming personal sin.

There may be an element of truth in that. Some Georgists grow flippant about their personal behavior, using their underlying Georgism as an excuse. Some speculate in land, saying that institutional wrongs are not cured by individual rights. The problem is that they forget that "where your treasure is, there will your heart be also" (Matthew 6:21). The older they get the tighter they cling to that treasure. If they do not, their wives and children will. I could name names, but so could you. The point here, however, is that this issue is not peculiarly RC. 
Some Catholics may believe that it is - that the RCC has the only pathway to salvation. Cardinal Josef Ratzinger said as much in 2000 and later, as Pope Benedict XVI, repeated it in July 2007 (Winfield 2007). Here we meet the problem of evil within the RCC itself. Even if one believes that the sacraments are divine, and that experiencing them will purify one from evil, the moral authority of the RCC and its officers has dropped in the last few years, following a long series of sex scandals, cover-ups, and hardball litigation against complaining victims. The Diocese of San Diego pleaded bankruptcy in 2007, and apparently lied to cover up the true value of its assets, according to Federal Bankuptcy Judge Louise De Carl Adler (Dolbee and Sauer 2007). In one ploy, they listed their landholdings at assessed values, far below market values. The Diocese of Los Angeles in July 2007 agreed to pay out $\$ 600,000,000$ to victims of abuse (Mozingo and Spano 2007). Protecting the Institution and its hierarchs has taken priority over serving the flock and healing the victims - a case of "goal displacement" parallel to what we see in secular institutions.

This is not the time or place to rub salt in these wounds. We seek reconciliation, and appreciate the many good works of the RCC and its communicants. Neither, however, is it the time for RCC spokesmen to preach "holier than thou." Denial and coverup have been tried and failed; it is time for disclosure and reform-a modern "counterreformation," if you will. We know the RCC can do it, for they did it before, led by the Jesuit Order itself.

\section{Specifics vs. Glittering Generalities}

Georgists are specific-some think TOO specific-about reform. Many of the religious, at the other extreme, expound glittering generalities but resist getting down to brass tacks. These religious are of all faiths. It is important to see the stars above, but also to keep our feet on the ground, muddy though it may be.

Rerum Novarum (Leo XIII 1891) (RN) and "The Son of RERUM," Quadragesimo Anno (Pius XI 1931) ( $Q A$ ), were more specific than most religions are at most times. $Q A$ especially came at a critical time when nations everywhere sought radical reforms, and it pointed a way. The 
problem was that many of these specifics turned out poorly, and some disastrously.

In the U.S.A., Fr. Charles Coughlin, pioneer radio priest, popularized both the Encyclicals as never before. Irish Catholic laymen like Raymond Moley, James Farley, Joseph Kennedy, and James Byrnes gained great power in the early New Deal, as did also Msgr. John A. Ryan of the National Catholic Welfare Conference (NCWC). Their best-known product was the National Recovery Act (NRA), known by its logo, The Blue Eagle. NRA was a cartelization of American industry supposedly modeled on Aquinas' ideas of guilds, elaborated in $Q A$ The Agricultural Adjustment Act (AAA) was the farm counterpart. NRA died, but AAA survives under other names.

Social insurance also fitted with $Q A$, although Dr. Francis Townsend, of no distinctive church affiliation, led the movement for old-age pensions. He was considered "screwball" and radical when he began, but Townsend quickly amassed millions of signatures and forced President Franklin Delano Roosevelt (FDR) to coopt his movement with the present Social Security program. In 1936 Townsend allied with Fr. Charles Coughlin, the radio priest who had popularized $R N$ and $Q A$, to push FDR further. Their politics failed, but their alliance indicates the compatibility of $Q A$ with Social Security.

Joe Kennedy, father of later President John F. Kennedy, led the new Securities and Exchange Commission (SEC). Generally, FDR depended on votes from big-city machines, many of them run by Irish Catholics, and wove their views into his policies. After Louis Howe died in 1936, Ed Flynn of the Bronx became FDR's chief strategist, urging FDR to the left, but still following signals from $Q A$. Raymond Moley, the right-wing Irish Catholic, had pushed business cartels, modeled on Aquinas' merchant guilds (but also drawing on earlier work by Charles Van Hise and Herbert Hoover). After Moley fell, Flynn, the left-wing Irish Catholic, pushed the Wagner Act, empowering labor unions, modeled roughly on Aquinas' craft guilds. Senator Robert F. Wagner of New York was a Catholic, too (of German extraction).

In the postwar period some of the New Deal social safeguards were dismantled, with at least the tacit approval of the postwar "American Pope," Francis Cardinal Spellman of New York. Spellman's gospel was 
anti-Marxism and raising money; his greatest financial angels were $\mathrm{Mr}$. and Mrs. Nicholas Brady.

At the same time, union organizer Cesar Chavez was inspired by RN under tutor Fr. Donald McDonnell, a worker-priest, and later enjoyed support from many Catholic bishops. Chavez needed RCC endorsement to fend off the inevitable McCarthyite attacks, backed by Spellman Catholics. Ironically, Fr. McDonnell's friendly persuasion was more weakening in the long run, as the guidance of $\mathrm{RN}$ focused Chavez on union organizing instead of tax reform, with its grander and more immanent effects.

In Europe, the history of $Q A$ was unfortunately bound up with the growth of Fascism (Rothbard 2004). Mussolini's "corporate state" supported and was supported by $Q A$. Worse, most of the fascist dictators of Europe were cradle Catholics, and weaned on RERUM and later, on its sequel, $Q A$ (Meyers 2009): Antonio Salazar in Portugal, Francisco Franco in Spain, Adolf Hitler in Germany, Benito Mussolini in Italy, Arthur Seyss-Inquart in Austria, Msgr. Jozef Tiso in Slovakia, Ante Pavelic in Croatia, Admiral Miklos Horthy in Hungary, Marshal Philippe Petain in France ... it is a long list, unrelieved by many exceptions.

\section{Noblesse Oblige vs. Governmental Reform}

We saw above how the Alabama Protestant churches put down Bob Riley and Susan Pace Hamill by arguing that an egalitarian tax system would weaken their character as voluntary donors to the poor. They also worried that the poor would regard welfare as an entitlement, instead of charity, and not be properly grateful.

In Europe, of course, the Catholic Church had been the welfare system of the middle ages, handling charity, medicine and education, These were to be financed by voluntary contributions, and/or from the rents of church lands, which were extensive and, since the church never sold, growing indefinitely. Private landowners have ever preferred voluntary donations to mandatory, since they may stop voluntary ones at will.

The Catholic welfare system was perhaps workable when there was just one church. Everyone belonged, everyone feared damnation, everyone kicked in. Today, however, Catholics are a minority of the 
population, with personal wealth and income below the average and falling, as Catholic Latinos enter at the bottom of the ladder. Besides Protestants and Jews there are now members of multiple Asian faiths with higher incomes and better prospects than the Latinos' (Singh 2011). Asian-American incomes average higher than EuropeanAmericans in California (California Pan-Ethnic Health Network 2012). Conditions are not right to replicate the Medieval system of Europe.

$R N$ speaks of worker associations to provide welfare for other workers, with no reference to property owners. Our Social Security system works on that basis, too, which is why it is so egregiously regressive. How about land owners? Should they not contribute to worker pensions? The original tithe that the Old Testament or Torah prescribes is on the produce of the land, not on wages and salaries or interest income (Meir 2007). Since $R N$, and perhaps earlier, the church's tithes have been on cash incomes, defined more or less the way the Internal Revenue Service (IRS) defines income in cash, omitting invisible incomes of the rich like unrealized capital gains, and imputed incomes of owner-occupied homes plus vast landed estates held for pleasure. Thus the churches lend their moral authority to the idea of defining tithe-able income the same way the IRS, subject to all manner of unholy lobbying pressures, defines taxable income. The net outcome is to tithe low and middle-income churchgoers to relieve landowners of their traditional tax and social obligations.

\section{Genetics versus Unjust Policies as Cause of Inequality and Poverty}

Leo XIII (1891) writes in $R N$ that differences in wealth arise from differences in "ability," meaning ability to serve mankind by producing more goods and services than others. Given that $R N$ is considered a milestone of liberalism in the RCC, one can imagine what attitudes prevailed earlier.

Protestants held similar ideas. James Madison (1787: \#10), a Calvinist, wrote as follows:

The diversity in the faculties of men from which the rights of property originate, is not less an obstacle to a uniformity of interests. The protection of these faculties is the first object of Government. . . .

The latent causes of faction are thus sown in the nature of man; . . the most common and durable source of factions, has been the various and 
unequal distribution of property. Those who hold, and those who are without property have ever formed distinct interests in society. ...

To secure the public good, and private rights, against the danger of such a faction, and at the same time to preserve the spirit and the form of popular government, is then the great object to which our enquiries are directed.

Such attitudes, coupled with racism, still prevail in the kinds of Protestant Alabama churches that rejected the theology and turned back the egalitarian tax reforms advanced by Professor Susan Pace Hamill and Governor Bob Riley. The (mostly) Protestant champions of eugenics believed the same, although Hitler, the greatest ethnic cleanser of modern times, was a cradle Catholic.

In the French Revolution, the anti-clerical leaders of the $3^{\text {rd }}$ Estate proclaimed the "Theory of previous accumulation", meaning we all started free and equal, and then some saved more, accounting for their wealth-for the $3^{\text {rd }}$ Estate represented successful merchants, not proletarians. This idea harks back at least to the Stoics and Epicureans, who saw it as an ahistorical assumption. It evolved later into a self-evident axiom, requiring no proof. "Rationalism (as of the Stoics) is essentially unhistoric, even anti-historic", said sociologist Franz Oppenheimer (1928).

Since then social scientists have found that differences in wealth are much too great to be explained that way. Marginal differences in height, strength, speed, or intelligence cannot begin to explain quantum differences in wealth, which spring from an acquisitive attitude, not a gene. Economic writer Amartya Sen (1981) has found that death by famine occurs almost solely in nations without democratic governments.

Many modern talk-show pundits preach that academics are "liberals" and "eggheads," meaning at once elitist and egalitarian. Overlooking the oxymoron, the fact is that the Department of History at Columbia University was for years the center of intellectual racism in America, under Professors William Archibald Dunning, John W. Burgess and Claude Bowers, who dominated the history of Reconstruction until recent times. For an idea of their views, see the 1915 film The Birth of a Nation or dip into Bowers' (1929) racist diatribe, The Tragic Era. Henry Steele Commager, Amherst historian, was considered a liberal 
stalwart, but when writing with Allan Nevins of Columbia, in their standard A Pocket History of the United States (Nevins, Commager, and Morris 1992), he signed on to the following sentiments, presented as objective history, assigned to millions of students:

Slavery "was designed to regulate the relationships of black and white rather than of master and slave" and the backwardness of the South was caused by "the presence of cheap and ignorant black labor-a situation that persisted long after emancipation" (p. 196). In 1850, Webster's support of the fugitive slave provisions of the compromise was "statesmanlike," a "great service to the nation," and "required high courage" (p. 201). In 1861, a southern advantage in the civil war was the "efficiency and organization of its agriculture" (pp. 217-281). In 1868, the impeachment of Andrew Johnson was "a disgraceful attack upon the constitutional integrity of the president" (p. 231). Emancipation should have been gradual, and "with due compensation to the slaveholders" (p. 234). Carpetbag regimes were extravagant, thieving and insouciant. Under sharecropping, "Farmers furnished their tenants with ... land ... The system seemed to work well and was so convenient" (p. 244). The landlord got $2 / 3$ of the crop.

This is not just pre-civil rights literature. Nevins and Commager's Pocket History was reissued in 1996 by the Trustees of Columbia University themselves, acting for the deceased Nevins. Even more recently, academic eugenics is rising again, in works like Herrnstein and Murray's (1994) The Bell Curve and Gregory Clark's (2007) A Farewell to Alms.

The point here is that genetic determinism is not peculiarly RCC. It may not be RCC at all, any more, for it is not clear that Leo's rationale for inequality represents either a majority or an "official" RCC view today. Georgist Robert Andelson, a professor of philosophy and an ordained Protestant minister, also preached eugenics, but on the whole his views are rare among Georgists. Most of them believe that nurture generally overrides nature in determining the fate of mankind.

\section{Sanctifying Land Tenures Derived from Invasion and Conquest}

Europeans of all faiths used religion, among other things, to rationalize their invasion and seizure of heathen and "empty" lands around the globe. Their Bible taught them that God Himself mandated the 
Israelites' invasion and seizure of the Holy Land, and vindicated it by promising it to them. Other peoples' gods may have promised it to them, too, but these were lesser gods. Modern Zionists, of course, are replicating this ancient movement, leading to strife without visible end or resolution.

In 1095 Pope Urban II called for the Crusades (Readings in European History I 1904: 312-316): "Wrest the land from the wicked race" quoth he, "and subject it to yourselves." We are paying the price today. In 1208 Pope Innocent III blessed Simon de Montfort's genocidal internal crusade against the cultured but heretical Albigensians and Waldensians of Toulouse and Languedoc. This paved the way for Louis IX to annex southern France and be sainted. Pope Gregory IX then assigned to Dominicans the long task of mopping up remaining heretics, beginning with The Papal Inquisition. It took a century or more. In 1486 Pope Innocent VIII confirmed Tomas Torquemada as Grand Inquisitor of several kingdoms of Spain which quickly absorbed the entire nation, rooting out Moors, Jews, and various egalitarian heretics, and of course seizing their lands, an important collateral benefit.

In 1494 Pope Alexander VI (Roderigo Borgia) rather immodestly cut the western hemisphere in two, between his native Spain and Portugal, pole to pole. The indigenes were not consulted-heathens were a nullity, and their lands regarded as no-one's. This presumption, however, was not peculiarly RCC. Soon Dutch, French and English empire-builders (and a few Danish, Norwegian, Swedish, Belgian, and Russian rivals) sent their missionaries to convert the heathen they had "discovered".

Imperialist religion was ecumenical. Protestant England built the widest empire of all, "bearing the white man's burden" of civilizing savages and spreading English versions of The Bible. Among other conquered victims were the Catholics of Ireland, whose lands were divided among the provocatively named "Protestant Ascendancy". Not until the Catholic Emancipation Act of 1829 could Catholics even serve in Parliament; and not for a century after that, if ever, did land reform rid Ireland of the Protestant Ascendancy.

Robert J. Miller's (2006) Native America, Discovered and Conquered gives a detailed account of how the doctrine of discovery worked its way into American law. 


\section{Original Sin versus Tabula Rasa}

Original Sin is not a peculiarly RCC doctrine. It is prominently associated with John Calvin of The Reformation. New England Puritans followed it. James Madison of Virginia was a Calvinist: he believed in original sin, and set up checks and balances to hold it and the popular will in check. The "sin" he most guarded against was the sin of dividing landholdings among all the people. He also tried to guard against an imperial presidency, an issue that hangs in the balance today in spite of all his efforts.

John Locke (1841), whom most Georgists revere, did not believe in original sin. In his classic An Essay Concerning Human Understanding he pictured the newborn's mind as a blank slate, or tabula rasa, to be filled up with experience and reflection, unbiased by either inborn sin or virtue. Locke also disputed the divine right of kings, who at that time in England were the RCC Stuarts, but there had been and would be Protestant monarchs as well.

It is from this presumption of a free, self-authored mind that Locke's doctrine of "natural" rights derives, and Locke's idea of property. The idea is that we own ourselves, and therefore own what we produce with our own labor.

The tabula rasa idea does seem to rule out original sin, but here we must reckon with St. Thomas Aquinas, whose ideas Leo XIII elevated as official RCC doctrine. Aquinas expounded tabula rasa long before Locke revived it. Aristotle (disputing Plato) published it even longer ago, and of course Aristotle influenced most of the early churchmen or "scholastics."

George had a more optimistic view of human nature; hence his faith in democracy, as direct as possible. This, however, is not a peculiarly RCC issue, since Calvin and others shared the RCC belief in original sin, and the RCC seer Aquinas expounded tabula rasa.

Rousseau believed we are born good; Rome banned his works. Machiavelli apparently believed people are born bad, and Rome also banned his works. Perhaps there is some kind of common principle behind that, but without more evidence it is not clear what it might be. 
The Rich versus the Poor

Cardinal Josef Ratzinger was sent to Latin America to put down liberation theology by tarring it as Marxist and therefore atheist and therefore sinful. He succeeded well, and returned to be chosen as Pope Benedict XVI. Returning to Latin America in 2007, Pope Benedict disappointed hopeful landless Latins by focusing his criticism on political leaders who purport, at least, to represent the landless. He was silent on the slaughter of 200,000 Guatemalans by landlord death squads following the CIA coup overthrowing President Jacobo ArbenzGuzman, the Contra war against the Sandinistas of Nicaragua, the assassination of Archbishop Romero and various nuns and priests, the Colombian war against the peasantry, the violent seizure of lands from Brazilian indigenes to free absentee owners to rape the Amazon, the crimes of Augusto Pinochet advised by faculty at the Catholic University in Santiago allied with Chicago economists, the "disappearances" in Argentina, and similar outrages. Peccadillos of the poor are magnified into menaces to civilization; mortal sins of the rich are overlooked.

One could probably match those Papal faults case by case by looking back in history at England's rape of Catholic Ireland, Russia's rape of Catholic Poland, the Southern protestant Church's support of slavery, Jackson's expulsion of the Cherokees, and so on. One could cite Jewish evictions of Palestinians.

In recent times the Protestant tyrannies have perhaps become more subtle, more indirect and worked through remote control, but none the less real. The smuggest, most reactionary sermon I ever heard was in the high-society New York Presbyterian on $5^{\text {th }}$ Avenue near $55^{\text {th }}$ Street. "Storefront" churches for the poor have been diverted from social issues into escapist mythology and, in some cases, orgies of mass hypnosis, while the richer fundamentalists, like those cited earlier, have merged their ideas of personal salvation with a new kind of social gospel that entails taxing the poor to help the rich.

\section{Dignity of Labor versus the Honor of Predation}

Catholics see dignity in work. So do many Protestants: "Work is Worship" is an old Puritan theme, part of the so-called "Protestant Ethic." 
Georgists certainly preach the dignity of labor; that is why they want to untax it, and why, like John Locke, they want to trace property rights back to labor. Now, academic economists have quietly subverted the working assumption first of George and later of Keynes that "full employment" is a worthy and primary goal of public policy. They slyly rationalize unemployment by calling it "leisure," which they treat as a product in itself-yes, some even want to include it in the measured Gross National Product! Work is a tradeoff with leisure, so the person at work is not much better off than if queuing at the soup kitchen. Sometimes common sense serves us better than clumsy efforts to be philosophical and universal.

Meantime, "work is worship" has also been twisted so as to rationalize exploitation of labor. Joe Hill the union man sang sarcastically in his 1911 song, "Work and pray, live on hay, there'll be pie in the sky in the sweet bye and bye when you die." Even worse was the Nazi's greeting at Auschwitz, "Arbeit macht frei."

Veblen (2006) in The Instinct of Workmanship writes that work and the sense of achievement can be gratifying per se. As Adele Wick says, a human is more than someone who seeks to satisfy desires with minimal effort, and the social and moral value of those desires should be examined. Veblen went on that wages are not paid so much to overcome the irksomeness of labor as the indignity of it, given the atavistic values of our rentier-led society, which labor itself has internalized. These values have us admiring predators and despising producers. George, of course, would turn that around; so would those religious who teach that work is worship. A reasonable combination of religious and economic truths would have it that a society is rich when products are cheap and labor is dear, as Tawney (1961) said, and when jobs are plentiful for those who want them.

\section{Tax-Exemption for Churches and Their Lands}

Georgists do not necessarily oppose exempting churches from taxation or publicly supporting church schools. Separation of church and state is not a peculiarly Georgist issue. There is a strong case for exempting churches, since they welcome all comers, contributions are voluntary, 
they inspire their people to behave better, and they patronize charity and education.

Georgists do opine, however, on how best to exempt churches, if that is to be done. What Georgists, along with most economists, object to is exempting institutions from property taxes while continuing to tax them on hiring and paying personnel. Other economists call this the "bricks and mortar" bias, but that name in turn reveals the bias other economists harbor against distinguishing land from buildings. Georgists favor exempting the bricks and mortar, the better to tax the land. What Georgists object to is the parking-lot and prime-location bias. Many a church whose attendance has dwindled occupies prime central land far costlier than its present congregation would pay for against other bidders.

One of the strongest arguments against taxing church buildings is that it is not possible to assess the market value of most of them, anyway. There is little market in used churches, especially those tailored for particular denominations. However, there is always a market for the land under churches.

It may have been this realization that explains the high heat of New York Archbishop Michael Corrigan's persecution of Fr. Edward McGlynn during and after 1886. Fr. McGlynn mobilized a huge following behind Henry George's program of exempting buildings and raising the tax rate on land values. This would have nullified one of Abp. Corrigan's grounds for exempting his (and other) churches from the property tax.

There is also a bias for long-term land speculation. Land appreciates over time and Georgists recognize the wisdom of taking these unearned increments in taxation. A century is but a moment in the life of the Catholic Church, which sees itself as eternal and takes a very long view. The Sisters of the Divine Word, a Catholic order, has owned a vast tract of land west of Winnetka, IL, between Northbrook and Glenview, since 1895, when it was just farmland, and rather swampy too. Now it is one of the most valuable locations in greater Chicago with its own post office, Techny. They lease parcels to major industries and merchants. The Cardinal of Chicago is often seen visiting. They have never had to sell, but if they did they would be exempt, like other eleemosynaries, from any capital-gains tax, as of today. If 
Georgists had their say, they would have been taxed not just upon sale, but upon rising market values year after year, for the last 113 years.

This issue is not, to repeat, peculiar to RCC lands. Everything said about Techny can be said in spades about Stanford University, a secular eleemosynary, and in a smaller way about the Loma Linda and California Baptist sectarian campuses in Riverside, California. It is, however, a source of uneasiness in the eleemosynary world, secular and sectarian, which helps explain their coolness to Georgist ideas.

\section{Issues That Are Peculiarly RCC}

\section{Democracy vs. Authority}

The word "authority" resounds through much RCC teaching, usually with a good ring. To many democrats and libertarians and creative thinkers and scientists the ring is bad. It evokes repression and tyranny and corruption of power and backwardness. It evokes Crusades, persecutions, inquisitions, Falangists, suppression of science, male chauvinism, tortures, burnings, stonings, massacres of Anabaptists and Cathars and Albigensians and witches, superstition, worship of relics and graven images ... a panoply of evils sponsored by "authority". It sounds un-American and, well, authoritarian.

That is to overstate the case, however. The views of many Catholics are more nuanced than the above suggests. Professor Charles Clark (2001) and others champion the "Principle of Subsidiarity": authority should reside in the smallest units that can handle the functions that require authority. Applied to governments, this principle suggests weakening national governments in favor of local governments.

I wonder, though, if Professor Clark would also apply the Principle to church organization? Here, it would seem to suggest less "ultramontanism" and more independence of American Catholics from Rome, as Fr. Edward McGlynn believed. Carried further, it would lead to Congregationalism, obviating the Vatican itself.

Applied to multinational corporations it would suggest breaking them up, as the Progressive administrations once broke up Standard Oil, in the golden age of anti-trust policy. Otherwise, if we weaken 
national governments by applying Clark's Principle of Subsidiarity, while abiding or fostering corporate giantism, we are left with unbridled corporate rule, which we seem to be approaching at high speed anyway.

As to authority vs. democracy, the choice is not as simple or clear as some of our popular democratic slogans would have it. Democracy can degenerate into plutocracy, as we observe today. Many primitive and half-literate citizens are easily misled into voting against their own interests. The Age of Enlightenment, supposedly democratic, actually fruited in the Age of Benevolent Despotism. A French Catholic monarchical agent like A.R.J. Turgot could see and speak the truth more plainly and directly than "democratic" writers like John Locke and Adam Smith, for in England one needed a rich patron whose personal interests were adverse to most other citizens.

Smith's patron, the Duke of Buccleuch, was England's biggest landowner. Smith had to tiptoe around His Grace to lay it between the lines. He also had to reckon with his friend Charles Townshend, author of the Townshend Acts, excise taxes that helped trigger the American Revolution. Today, extension of our "democracy" into unwilling foreign nations is widely regarded as a sham, a cover for plutocratic imperialism, petrolocracy, and kleptocracy.

Modern public schools, originally so promising, come increasingly under the sway of small-minded petty bourgeoisie who suppress any teaching about economic justice such as the Catholic monarchist Turgot (1913) urged, and instead are reviving the anti-scientific spirit of Dayton, Tennessee and the Scopes Trial.

Turgot and the Physiocrats, some of the clearest economic thinkers of all time, were part of the French monarchy. Turgot championed, among other things, a school system where sound economic studies (like his) would be required of all students. Napoleon, the autocrat, probably did more to spread ideas of economic justice around Europe than any democrat. More recently some of the best examples of applied Georgism, as in Hong Kong, Kiaochow, Taiwan and Singapore, were imposed by foreign powers.

The ancient Jews set up a separate class of Levites who owned little land, and whose job was to teach The Covenant to others who did. Thus it is conceivable that the Catholic school system might become 
a vehicle for conveying Levitical ideas of justice to a new generation of students. If so, however, if would call for a different set of directives from the new Pope Benedict XVI than he has ever uttered. It would call for a new College of Cardinals and probably an entirely new way of screening papal candidates.

\section{Aquinas versus Free Markets}

Aquinas, endorsed by Leo XIII and all of his successors, believed in substantial regulation of free markets, without much or any confiscation or taxation of land rents. This belief was applied with religious zeal in the 1930s in FDR's New Deal, and, with a fascist twist, in Mediterranean and Central European nations. Following the Great War it was reapplied by post-fascists in the social democracies, where leaders like Schumann, De Gasperi, Adenauer, and others had learned their Encyclicals early on. (English and Scandinavian socialism had other roots.)

Ludwig Erhard, father of Germany's free market Wirtschaftswunder, was a Protestant. He was an academic product and disciple of Franz Oppenheimer (1928), a scholar whose works criticizing the right of conquest, large landholdings, and the exploitive state contain many Georgist themes. Erhard was often at odds with Adenauer, who aimed to unify the Catholic nations of Europe.

Modern Georgists lean more towards laissez-faire, free markets, and the price system. They count on taxing land values to achieve social justice and economic security, reasonably free of regulations and price controls. Let us not overstate this difference, however. Henry George himself remained a labor-union member to the end. He favored public regulation or outright ownership of rails and public utilities-burning issues in his day. So did most politically active Georgists throughout the Progressive Era.

George, married to a Catholic, allied with socialists in the election of 1886. Following that, the extremists on both sides set to feuding until their alliance exploded in faction. (One suspects the work of agents provocateurs on both sides.) It is not that modern Thomists would accept the "socialist" label, which to them carries baggage they reject. However, with a little semantic sophistication on both sides, a 
little distinguishing of the essential from the incidental, and careful avoidance of agents provocateurs, it should be possible to unite on a common core of beliefs.

It is worth remembering that the mayors of Milwaukee from 19101912, and again 1916-1950, were nominal "socialists" who implemented a good deal of Henry George's program. Morris Hillquit of New York, a doctrinaire socialist, dismissed them and Mayor Dan Hoan with a sneer as mere "sewer socialists". Socialist Mayor Daniel Hoan (originally Hogan) (1916-1940) was also a Catholic. Milwaukee was and is heavily RCC (German, Polish, Italian, and Irish). These good Catholics were not scared by the fright-word "Socialist!" Socialist Norman Thomas always included a Georgist plank in his platform. Upton Sinclair fused Georgism with quasi-socialist programs.

Aquinas believed in "just price" enforced by controls if need be. Georgists who believe in the price system preach against such controls. My advice is, leave that to ordinary neo-classical economists; it is their main stock in trade. Georgist time is too precious and our task is harder. Remember, also, the violent reaction against Turgot when he suddenly decontrolled the price of grain, 1774-1776. Sometimes a good idea must be eased in and explained at length. There are always ignorant and excitable spirits out there, studiously stirred by calculating ones, to make trouble for good leaders.

Aquinas would also cap interest rates, and $R N$ and $Q A$ echo that. This is a tougher nut to crack. My first hope is that most Catholics have moved on from this position. My greater hope is that more people will realize that land speculators, above all men, love low interest rates, because they push up land prices. This is a point on which ordinary neo-classical economists are remarkably obtuse. It wants constant reaffirmation: land rents vary inversely with interest rates. In addition, price/rent ratios vary inversely with interest rates, redoubling the effect.

\section{Who Owns Us: Ourselves, God, or the State?}

Georgists follow John Locke, who posited that we own ourselves and therefore the things we make. That is the basis of property rights, said Locke. 
Brian Benestad (2012) writes that Catholics do not believe we own ourselves. That is why suicide is a sin. However, suicide is so rare that that is hardly the main point. What it does is help rationalize forms of taxation that take from labor. It might help rationalize military drafts.

More recently, the idea we do not own ourselves helped rationalize the payroll tax introduced in the peak of RCC influence on the New Deal. (Francis Townsend, who instigated the system, had wanted a sales tax, which is bad enough, but at least would have raised money from rentiers as well as workers.) Then it rationalized withholding of taxes from payrolls (Beardsley Ruml, a Czech-American Catholic and Rockefeller man, and Milton Friedman, of Jewish extraction but unknown religious views, teamed to introduce withholding). Note that Friedman and Ruml subjected only wage income to withholding. Property income soon evolved into the major tax shelter.

Catholic Georgist economist Terence Dwyer (1980) of Australian National University points out that it is God, not the state, who owns our bodies. He sees the RCC doctrine as a safeguard against state slavery, not an adjunct to it. Surely there are cases in point, from Thomas More to Martin Luther King, Jr. The first levée en masse was introduced by anti-clericals in the French Revolution. There are also opposite cases, as when we are urged to pay taxes and support tyrants and murder strangers "for God and Country." One might conclude that neither organized religion nor patriotism can substitute for individual wisdom and judgment and responsibility. This brings us back, however, to the point that we own ourselves, even to the point of choosing when to serve God or the state.

Now, however, rentiers who craft and dominate our public philosophies have reframed them so that property in land is sacred, while labor's civic duty is to pay taxes, including huge debts incurred to enhance land values and spare property from taxes. Thus the state owns a major equity in labor, including unborn laborers, but may not tax property at rates above very low caps. The Catholic Church seems to have gone along with this, at least in part. In 1992 the Catholic catechism was changed to make tax evasion a sin. Perhaps this was aimed at rich evaders, but an article in the New York Times by David Cay Johnston (2007) couples this with implied Catholic support for jailing tax-protesting pacifists. 


\section{Gender Issues}

Clerical celibacy is under increasing attack. It is hardly found in other religious institutions, not even in the Greek Orthodox communion, which considers itself to be the true and original Catholic Church. Critics are linking the pedophilia problem to celibacy (Sommer 2011), although many earnest defenders deny that (Crisis E-Letter 2002). Opposition is nothing new: Fr. Edward McGlynn, the Georgist Catholic, spoke out against it as long ago as the 1880s, and it has withstood other attacks. In our times the growing shortage of priests and nuns may yet force changes. Meantime, clerical celibacy in the RCC remains a "peculiar institution" in modern society. While it sets Catholics apart, it does not by itself block understanding and cooperation between Georgists and Catholics. However, to the extent it is part of a Gestalt denying women's rights, there is an issue.

George and his followers led prominently in movements for women's rights. Carrie Chapman Catt led the successful struggle for the $19^{\text {th }}$ Amendment (votes for women) and went on to found the League of Women Voters. It is less well known that Newton Baker tried in 1920 to enlist her to run with Brand Whitlock or William Gorgas on the Single Tax ticket for Vice-President of the U.S.

However, Georgist causes have gone downhill ever since women got the vote, and there may be some causal connection. Many older widows, in particular, are small rentiers since men have the better jobs, and die younger. Women actually own (slightly) more property than men. As women become more independent, and win equal pay for equal work, these attitudes may slowly change, but meantime Georgists face a major problem.

The movement against exploitation of child labor had brought feminist and Georgist leaders together. Jane Addams, Julia Lathrop, Louis F. Post, and Scott Nearing worked together for this cause. $R N$, on the other hand, pulled back from demanding a "family wage" for adult male workers, thus leaving open the interpretation that women and children should join the hired labor force, as children did then, and women do now. Employers were simply not to assign them tasks beyond their capacity, presumed to be inferior. "Rosie the Riveter" did not come along until World War II. 
The RC priesthood is closed to women. So then, of course, are all the leadership positions in the hierarchy. It is an exclusive men's club; women may not even exert indirect influence as priests' wives. Female religious are mostly restricted to serving as nuns. To the outsider this seems like an anachronism. Some Georgists would not make an issue of it, so long as the RCC women accept it voluntarily, but others are feminists who see such male bastions as unworthy of tax exemption or subsidies.

One could argue, with RC writer E. Michael Jones (1993) that employer interests fostered feminism in order to lure women into the work force, lowering wages and weakening labor unions. Jones weaves a fascinating thesis combining St. Augustine, Freud, advertising guru Eddie Bernays (Freud's nephew), Freudian A.A. Brill, the Rockefellers, behaviorist John Watson, G.W. Hill of American Tobacco, Protestant and liberal-dominated Madison Avenue, Robert Yerkes, Joseph Goebbels, British agent William Stephenson, Beardsley Ruml, Vance Packard and Alfred E. Kinsey. On the other hand, Jones does not take into account $R N$ s unwillingness to advocate a "family wage". It would take a career to unravel Jones's interwoven plots, but they contain enough truth to be evocative and challenging. Watson, for example, was the Dr. Spock of the 1920's, yet has now, but for Jones, been thrust down the memory tubes of history. I pass no judgment on Jones' claims, other than that they are novel and challenging. It is true, however, that the combined competition from female, immigrant and foreign labor, encouraged by employing interests, has lowered normal male wage rates in the last century.

The parochial school system has depended heavily on the work of celibate nuns receiving minimal compensation. The women's liberation movement of the 1960s found a ready audience among many such nuns who began to see themselves as exploited. Some left their orders; recruitment fell off, and schools had to replace them with lay teachers at competitive salaries. Tuition then rose, attendance fell, and the system has shrunk, in spite of the modern political movement for replacing public schools with private and religious ones. The RCC response is to agitate for a voucher system that does not bar the use of vouchers in religious schools. Individual Georgists 
may support or oppose that for their own reasons, but Georgism per se would ask only that the vouchers be financed from taxes on land value.

It is past time the Vatican redirected its energies from damning gay marriage to damning pedophilia and alcoholism among its own shepherds. A few years ago Catholic World News (2002) reported that the rate of AIDS among priests was four times the national average. Catholic novelist Graham Greene has made the "whisky priest" a literary type.

As to abortion, there is no clear "Georgist" position on that tortured question, nor have I authority to declare one. As for my own opinion, it is mixed. I would resist having a child of mine aborted in the womb, but then, I've never had a womb or a pregnancy, which narrows my perspectives. My feelings should carry less weight than the females', for they are more directly involved. I am impressed by some modern feminist writers who document the history of forced maternity in the slave-breeding states, 1808-63, and who liken modern enforced maternity to the older slave-breeding industry. Like all analogies, however, this one is imperfect, and I will leave it unresolved here.

It would be good if we could somehow make women alone eligible to vote on abortion laws, but that is probably impractical. Meantime, it seems somehow wrong to give much weight to the RCC position so long as it is determined by men alone, and celibate men at that, as now.

Whether Georgists and Catholics can breach these barriers depends on motivation, and the quality of leadership on both sides. The challenges are daunting, but not irresolvable, for there are no irresolvable problems.

\section{Points of Similarity and Agreement}

\section{Natural Law, Rights, and Justice}

Both Catholics and Georgists give great weight to natural law and rights. These ideas have been rejected by professional philosophers, and much of the intellectual world, leaving Catholics and Georgists as natural allies to defend them. 
We are not alone, however. There are millions more Catholics than professional philosophers, and millions more Protestants and Muslims and others who believe in natural rights. These "have legs," going back at least to Lao-tze in 500 B.C., and are firmly embedded in our culture: in Jewish and Christian doctrine, the English Bill of Rights (1689), the American Declaration of Independence (1776), the Massachusetts Declaration of Rights (1780), the French Declaration of the Rights of Man (1789), the $9^{\text {th }}$ and $10^{\text {th }}$ Amendments to the U.S. Constitution (1789), the Gettysburg Address (1863), the United Nations Declaration of Human Rights (1946), and more orations and sermons than you could count. The Declaration of Independence never made it into the U.S. Constitution, but it is found in many state constitutions, including California's. As unlikely a source as Rush Limbaugh opines occasionally that there are natural rights, God-given and unalienable.

Ironically, the Enlightenment philosophers, who are thought to have undermined Catholicism with their Deism, also generally believed in Natural Law and Rights. Turgot the land-tax champion declares it specifically. Some champions of the legal Public Trust Doctrine even claim that it somehow precedes and trumps all manmade laws.

\section{Plain Talk versus Gobbledegook}

Both Georgists and Catholics view much modern economic literature as pretentious trash. Alas, the disdain is mutual, for most professional economists today see us as "outside the mainstream"-mainstream meaning themselves. Their hostility long preceded the rise of technobabble, however, and has other causes like the spontaneous comity of property (Gaffney and Harrison 1994). Our reasons for disdain are nothing new, and were expressed long ago by Erasmus (1876), by Baruch Spinoza (1883), by Jonathan Swift (1892), and by the very John Locke we have been discussing. Here is Locke (1841: The Epistle to the Reader):

It is ambition enough to be employed as an under-labourer in . . removing some of the rubbish that lies in the way to knowledge, which certainly had been much more advanced in the world if the endeavors of ingenious and industrious men had not been much cumbered with the learned but 
frivolous use of uncouth, affected, or unintelligible terms.... Vague and insignificant forms of speech, and abuse of language, have so long passed for mysteries of science ... that it will not be easy to persuade either those who speak or those who hear them that they are but the covers of ignorance, and hindrance of true knowledge."

Open almost any modern economics journal and you will see how little the world has advanced since 1690, in spite of Locke's efforts. If the intellectuals ever heeded him, they have regressed. It's a massive herd behavior, hard to stem.

The Catholic Review of Social Economics is one of the few journals that maintains some readability, and Notre Dame has long been a haven for "heterodox" economists who strayed from the flock. Alas, its administration finally caved under the pressure of methodological correctness and reined in its heterodox Department-much as the University of California Riverside Administration did 15 years ago.

The Georgist-inspired American Journal of Economics and Sociology is another haven for independent individualistic writers. Perhaps the editors of these two journals should get together and explore their common interests.

\section{Anti-Malthusianism}

Georgists and Catholics both deny that population control is the panacea for apparent resource scarcity. The Georgist position goes back to George's long campaign to get good lands used better, with the corollary of constraining settlement sprawl: not just urban, but also rural, sylvan, extractive, hydraulic, and what have you. It needs tweaking today to incorporate the role of taxes based on extraction and pollution. I will let others articulate the RCC position. To an outsider it looks like a tradition too single-mindedly based on the sanctity of the individual human life, without much thought for the aggregate and long-term effects on human or non-human life.

\section{Conclusion}

I was pleasantly surprised, as I worked along, how few of the stumbling blocks I had listed are peculiar to Roman Catholicism; 
and how many are passable without stumbling. The ones listed in as "Peculiarly RCC" may remain, but I am optimistic that with good will on both sides we may find pathways through, over, around or under them, to work together towards our common goals. I have not minced words to avoid tough problems, but tried to define issues clearly as a prelude to resolving them. Catholics of good will will not take offense, but detect the search for reconciliation beneath my frank words. I look to Catholic Georgists like John Kelly, Bryan Kavanagh, David Kromkowski and Terry Dwyer to carry this resolution further.

\section{References}

Benestad, B. (2012). "A Catholic Response to Henry George's Critique of Pope Leo XIII's Rerum Novarum." American Journal of Economics and Soci$\operatorname{ology}$ (this issue).

Bowers, C. G. (1929). The Tragic Era: The Revolution after Lincoln. New York: The Literary Guild of America.

California Pan-Ethnic Health Network (2012). "Median Household Income, (California, 2006)." http://www.cpehn.org/demochartdetail.php?btn_ viewchart=1\&view_137.x=47\&view_137.y=14.

Catholic World News (2002). "The Gay Priest Problem" (June 3). http:// www.catholicculture.org/news/features/index.cfm?recnum $=20565$.

Clark, C. (2001). "Catholic Social Thought and Economic Transition." Review of Business (Fall).

Clark, G. (2007). A Farewell to Alms: A Brief Economic History of the World. Princeton, NJ: Princeton University Press.

Crisis E-Letter (2002). "10 Myths about Priestly Pedophilia." http:// www.catholiceducation.org/articles/facts/fm0011.html.

Dolbee, S., and M. Sauer (2007). "Judges Tears, Rebuke Close Case." UnionTribune (November 2). http://www.bishop-accountability.org/news2007/ 11_12/2007_11_02_Dolbee_JudgesTears.htm.

Dwyer, T. M. (1980). "A History of the Theory of Land Value Taxation," Ph.D. dissertation. Cambridge, MA: Harvard University.

Gaffney, M. (2000). Henry George, Fr. Edward McGlynn, and Pope Leo XIII. New York: The Robert Schalkenbach Foundation.

Gaffney, M., and F. Harrison (1994). The Corruption of Economics. London: Shepheard-Walwyn.

Johnston, D. C. (2007). "Professor Cites Bible in Faulting Tax Policies." New York Times (December 25). http://www.nytimes.com/2007/12/25/business/ 25tax.html. 
Leo XIII (1891). "Rerum Novarum." In George, H., 1941, The Land Question Etc., New York: Robert Schalkenbach Foundation: 109-151. Also in Molony, J., 1991. The Worker Question. A New Historical Perspective on Rerum Novarum. North Blackburn, Victoria, Australia: Collins Dove.

Jones, E. M. (1993). Degenerate Moderns: Modernity as Rationalized Sexual Misbehavior. Fort Collins, CO: Ignatius Press.

Locke, J. (1841). An Essay Concerning Human Understanding, $29^{\text {th }}$ edition. London: Thomas Tegg.

Madison, J. (1787). "The Federalist No. 10: The Utility of the Union as a Safeguard Against Domestic Faction and Insurrection." Daily Advertiser (November 22). http://www.constitution.org/fed/federa10.htm.

Meir, A. (2007). "Anti-Aristocracy." Jewish World Review (August 6). http:// www.jewishworldreview.com/jewish/ethicist_tithing.php3.

Meyers, W. P. (2009). "Pius XI and Fascism in Austria." Point Arena, CA: III Publishing. http://www.iiipublishing.com/religion/catholic/popes/ pius_xi_austria.html.

Miller, R. J. (2006). Native America, Discovered and Conquered: Thomas Jefferson, Lewis \& Clark, and Manifest Destiny. Westport, CT: Praeger.

Mozingo, J., and J. Spano (2007). "\$660-Million Settlement in Priest Abuses." Los Angeles Times (July 15). http://articles.latimes.com/2007/jul/15/local/ me-priests15.

Nevins, A., Commager, H. S., and Morris, J. (1992). A Pocket History of the United States, Ninth Revised Edition. New York: Pocket Books.

Oppenheimer, F. (1928). The State: Its History and Development Viewed Sociologically, tr. J. Gitterman. New York: Vanguard Press.

Pius XI (1931). Quadragesimo Anno: Encyclical of Pope Pius XI on Reconstruction of the Social Order. http://www.vatican.va/holy_father/pius_xi/ encyclicals/documents/hf_p-xi_enc_19310515_quadragesimoanno_en.html.

Rothbard, M. N. (2004). "Catholicism and Capitalism." Auburn, AL: Ludwig von Mises Institute. http://www.lewrockwell.com/rothbard/rothbard59. html.

Singh, R. M. (2011). "American Religious Affiliation versus Household Wealth." http://americanturban.com/2011/05/12/american-religious-affiliation-vshousehold-wealth/.

Sommer, J. C. (2011). "Clerical Celibacy and Pedophilic Priests." http://www. humanismbyjoe.com/clerical_celibacy_and_pedophilic.htm.

Spinoza, B. (1883). Ethics, tr. R.H.M. Elwes. Murfreesboro, TN: Middle Tennessee State University Philosophy WebWorks. http://frank.mtsu.edu/ $\sim \mathrm{rbombard} / \mathrm{RB} /$ Spinoza/ethica-front.html.

Swift, J. (1892). Gulliver's Travels. London: George Bell and Sons.

Tawney, R. H. (1961). Religion and the Rise of Capitalism. New York: Penguin Books. 
Turgot, A. R. J. (1913). "Memorandum on Local Government." In Oeuvres de Turgot, ed. G Schelle). Paris: Alcan. http://chnm.gmu.edu/revolution/d/ $255 /$.

Veblen, T. (2006). The Instinct of Workmanship and the State of the Industrial Arts. New York: Cosimo, Inc.

Winfield, N. (2007). "Protestant Leaders Upset by Benedict's Vatican II Correction." Union Tribune (July 11). http://www.signonsandiego.com/ uniontrib/20070711/news_1n11church.html. 


\section{AUTHOR QUERY FORM}

Dear Author,

During the preparation of your manuscript for publication, the questions listed below have arisen. Please attend to these matters and return this form with your proof.

Many thanks for your assistance.

\begin{tabular}{|l|l|l|}
\hline $\begin{array}{c}\text { Query } \\
\text { References }\end{array}$ & \multicolumn{1}{c|}{ Query } & Remark \\
\hline $\mathrm{q} 1$ & $\begin{array}{l}\text { AUTHOR: A running head short title } \\
\text { was not supplied; please check if this } \\
\text { one is suitable and, if not, pleses supply } \\
\text { a short title of up to 40 characters that } \\
\text { can be used instead. }\end{array}$ & \\
\hline
\end{tabular}

